\title{
Turn down the heat: regional climate change impacts on development
}

\author{
Christopher P. O. Reyer ${ }^{1}$ (D) Kanta Kumari Rigaud ${ }^{2}$ - Erick Fernandes ${ }^{2} \cdot$ William Hare $^{3}$. \\ Olivia Serdeczny ${ }^{1,3} \cdot$ Hans Joachim Schellnhuber ${ }^{1}$
}

Received: 11 June 2017 / Accepted: 11 June 2017 / Published online: 4 July 2017

(C) Springer-Verlag GmbH Germany 2017

\section{Introduction}

The Paris Agreement, a landmark in international climate policy, advocates "holding the increase in the global average temperature to well below $2{ }^{\circ} \mathrm{C}$ above pre-industrial levels and pursuing efforts to limit the temperature increase to $1.5^{\circ} \mathrm{C}$ above pre-industrial levels". Achieving the Paris agreement is ambitious, because time for bringing humanity on a sustainable development pathway is short. Warming in 2016 has reached $1.1^{\circ} \mathrm{C}$ as compared to the pre-industrial (18801900) average (WMO 2017) and current emission reduction pledges presented for the COP21 in Paris will lead with 50\% probability to a global warming of about $2-3{ }^{\circ} \mathrm{C}$, and with $34 \%$ probability to about $3-4{ }^{\circ} \mathrm{C}$ until 2100 compared to

Christopher P. O. Reyer

reyer@pik-potsdam.de

Kanta Kumari Rigaud

kkumari@worldbank.org

Erick Fernandes

efernandes@worldbank.org

William Hare

bill.hare@climateanalytics.org

Olivia Serdeczny

olivia.serdeczny@climateanalytics.org

Hans Joachim Schellnhuber

director@pik-potsdam.de

1 Potsdam Institute for Climate Impact Research (PIK) Member of the Leibniz Association, Telegrafenberg, P.O. Box 601203, 14412 Potsdam, Germany

2 The World Bank, 1818 H Street NW, Washington, DC 20433, USA

3 Climate Analytics, Ritterstraße 3, 10969 Berlin, Germany pre-industrial levels (Fawcett et al. 2015). Climate change impacts in a broad range of physical, biological and human systems have already been attributed to the observed warming for most regions of the World and are projected to further intensify (IPCC 2014). Particular risk is being attributed to climate change impacts that interact across sectors and spatio-temporal scales and lead to a cascade of impacts threatening development endeavours (Schellnhuber et al. 2012; Piontek et al. 2014).

However, currently, there is still a lack of detailed knowledge about the progression of climate change impacts from environmental systems to human systems in different world regions as the world moves from current warming towards a $1.5^{\circ} \mathrm{C}, 2^{\circ} \mathrm{C}$ or even a $4{ }^{\circ} \mathrm{C}$ world. This pertains not only to the frequency, intensity and magnitude of impacts but also to their mutual interaction and reversibility. Impacts may for example be non-linearly related to temperature increase and/or may result in a cascade of impacts where biophysical impacts trigger crucial impacts in human systems across different sectors that may turn out to be irreversible at least on human timescales. Henceforth, assessing the vulnerability of social systems towards climate change is a crucial knowledge gap that may threaten current and future development initiatives.

This special feature builds on and extends the data and literature collected for the Turn Down the Heat report II and III (Schellnhuber et al. 2013, 2014), commissioned by the World Bank, to answer the following questions in different regions of the world:

I. What are the key biophysical climate change impacts in different world regions under different degrees of warming $\left(1,1.5,2\right.$ and $\left.4{ }^{\circ} \mathrm{C}\right)$ ?

II. What are the crucial development impacts triggered by biophysical climate change impacts within and across sectors in these regions? 
III. What are the implications of climate change impacts (physical, biophysical and social) for the (differential) social vulnerability within these regions?

This special feature examines biophysical impacts under different warming scenarios $\left(1,1.5,2\right.$, and $4{ }^{\circ} \mathrm{C}$ warming $)$ and considers scientifically derived development impacts to gain a better understanding of vulnerability to climate change. The main contributions to this special feature are five regional impact papers summarizing climate impacts in Sub-Saharan Africa (SSA, Serdeczny et al. 2017), South Asia (SA Vinke et al. 2017), Central Asia (CA, Reyer et al. 2017a), Latin America and the Caribbean (LAC, Reyer et al. 2017b) and Middle East and Northern Africa (MENA, Waha et al. 2017) (Fig. 1). Each paper is structured in a way that first the physical and biophysical impacts in each region are highlighted and then their implications for impacts in key human systems. This allows to display how climate change impacts cascade from the strict physical effects into socio-ecological systems. Each regional paper closes with a synthesis of selected development impacts to be expected within and across different sectors, the so-called Development Narratives. A sixth paper by Otto et al. (2017) reviews the scientific literature on differential social vulnerability to climate change determining social and demographic groups most vulnerable to climate change impacts.

In the following, we briefly introduce the common methodology underlying the regional impact papers and discuss how the Development Narratives contribute to piecing together the often non-systematic evidence from individual climate impact studies.

\section{Five diverse regions - one common methodology}

The five regional impact papers presented in this special feature were all based on a common methodology combing (1) an in-depth literature review of regional climate impact studies with (2) an original analysis of climate and sea-level rise projections and (3) a co-production of knowledge process to develop the Development Narratives.

\section{Literature review}

We reviewed the peer-reviewed scientific literature on climate change impacts in each region. We focussed on the English literature; very few references were also taken from national languages. The climate impacts identified in the literature review were in most cases not referring to global warming levels but usually based on regional warming levels specific to each individual study. While the latter makes sense when considering an impact study in its regional context, relating the regional impacts to global warming levels is required for global climate policy. Therefore, wherever possible, we derived global warming levels for the impact studies analysed in the regional impact papers based on models and scenarios from the CMIP3 or CMIP5 database (Schleußner and Mengel

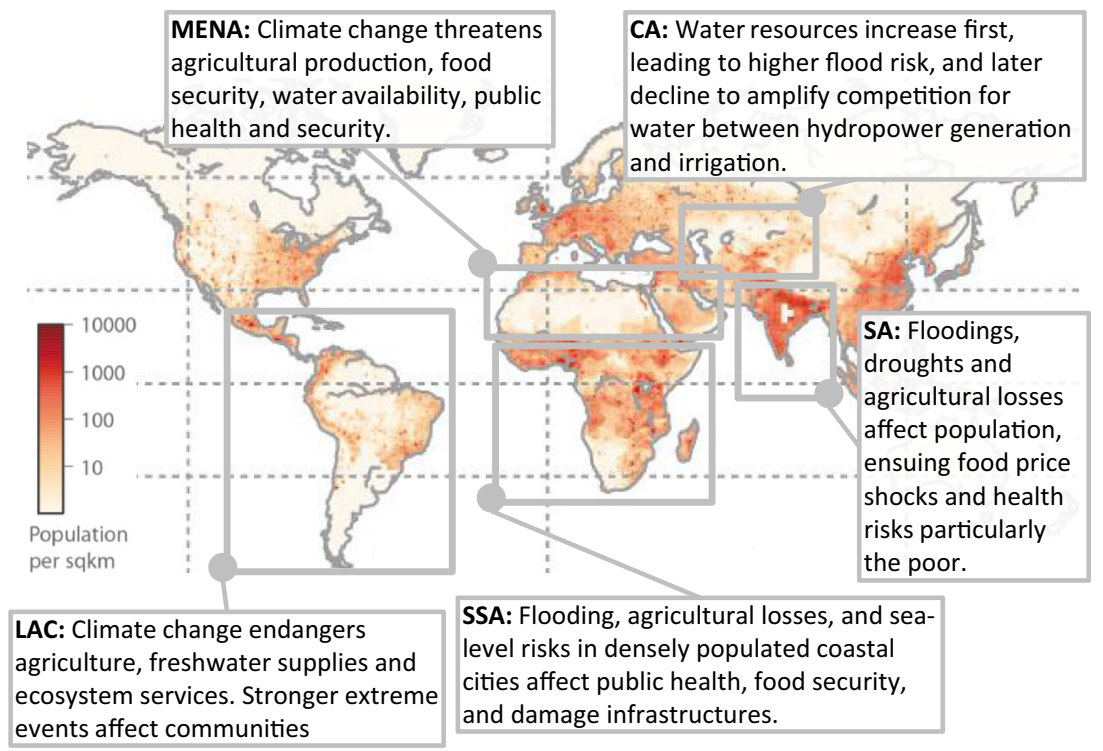

Fig. 1 Synthesis of key climate change impacts in the different world regions covered in this special feature. The background map shows estimates of the world population in 2080 experiencing monthly boreal summer temperatures (JJA, averaged over centred 20-year time intervals) classified as 3-sigma events (3-Sigma deviation from mean value, expressed as the possible year-to-year changes in local monthly temperature because of natural variability) for the RCP8.5 $\left(4{ }^{\circ} \mathrm{C}\right.$ world). Population estimates are based on the Shared Socioeconomic Pathway 2
(SSP2) and shown in terms of population density. The basis for the gridded population estimates is the National Aeronautics and Space Administration GPWv3 y-2010 gridded population dataset, which is linearly scaled up on a country basis to match the SSP projections, thus neglecting population redistribution within countries. The SSP2 population estimates on country basis with 5 -year time steps were obtained from the SSP database as in Schewe et al. (2014) 
2017). This allowed us to attribute climate changes on a regional scale to their respective global warming level.

\section{Climate projections}

The climate data were based on two Representative Concentration Pathways (RCPs 2.6 and RCP8.5) from five General Circulation Models (GCMs, namely GFDL-ESM2M, HadGEM2-ES, IPSL-CM5A-LR, MIROC-ESM-CHEM, NorESM1-M). The GCM data were interpolated to a $0.5{ }^{\circ} \mathrm{C}$ resolution and bias-corrected as part of the Inter-Sectoral Impact Model Intercomparison Project (ISIMIP, Warszawski et al. 2014). Please see Schellnhuber et al. (2014) for a detailed description of the climate data.

\section{Sea-level rise projections}

The sea-level rise projections in the SSA and SA regions were based on a semi-empirical approach (Rahmstorf 2007; Schaeffer et al. 2012), while for LAC and MENA a processbased approach has been used (based on Hinkel et al. 2014; Church et al. 2013). The latter reflects increases in knowledge as presented in the IPCC AR5 (IPCC 2013) and leads to slightly more conservative sea-level rise estimates. However, the upper bounds are comparable under RCP8.5 and they are the most relevant from a risk assessment perspective (c.f. Schellnhuber et al. 2014 for a detailed discussion of the two approaches).

\section{Co-production of knowledge}

The regional impact papers presented in this special feature assess the risks climate change poses to development in each region by synthesizing the biophysical, ecological and human impacts of climate change into the Development Narratives at the end of every paper. The Development Narratives cover a large range of changes, from projections of global temperature increase and precipitation changes to observed human impacts on the ground and highlight the implications of climate impacts for key development issues in each region. They present plausible ways in which climate impacts may unfold, based on the information we have today. Dense by design, they focus on the wider picture and possible interactions between impacts described in the literature and do not aim to provide detailed descriptions of each impact and associated uncertainties. Each Development Narrative was written by multiple authors of different disciplinary backgrounds. Reflecting the learning process that this approach has entailed, the production of the third Turn Down the Heat report (Schellnhuber et al. 2014) also included a workshop which brought together climate impact scientists, regional disciplinary-oriented scientists and regional development experts from the World Bank (see Fig. 2 for a representation of the process of co-production of knowledge in the project). This inter- and transdisciplinary interaction between scientists and stakeholders continued through a sustained iterative writing of the Development Narrative texts themselves.

\section{Piecing things together: on the value of the Development Narratives}

The Development Narratives take a special position within the analysis of climate impacts on development presented in this special feature. They present the outcome of applied transdisciplinarity. Through the iterative writing process, authors were forced to engage in concepts foreign to their own disciplines. Within the small writing teams, the misunderstandings that come with such engagement could be clarified and overcome. It was our experience that the tacit associations that come with each term according to its embeddedness in different world-views needed to be made explicit and clear without settling for a particular definition or interpretation. This reflects the suggestion that linguistic inconsistency can be a major obstacle to interdisciplinary work (Newell et al. 2005; Füssel 2007). However, at this fundamental stage of cross-disciplinary integration, the appreciation of multiple perspectives was what was aimed for rather than a homogenization of views.

The narrative style of assessment sensitizes different research communities to the value-dimensions that come with applying indicators representing human well-being. In a world of finite resources and necessary trade-offs, aggregation of indicators to allow for comparability is often sought for. However, aggregation comes at a high price. As the notion of multi-dimensional poverty indicates, poverty is a human experience and is highly context-dependent (Leichenko and Silva 2014). Critical reflection is thus required as to which scale and metric is most appropriate for assessing the risks that climate change poses for development. Global aggregates, for example, often mask important regional differences in vulnerability and consequently the degree of impact (Tschakert 2015) and yield no insights into the distributive effects of climate impacts. Further, what counts as valuable might often be a matter of perspective (Morrissey and Oliver-Smith 2013). For example, the perceived value of territory lost to sea-level rise will differ across regions depending on cultural assets and emotional attachment to place (Albrecht et al. 2007; Tschakert et al. 2013). Working on a common narrative in a trans- and interdisciplinary setting can promote an appreciation of such culturally specific value judgements, which, combined with the sober quantification of impacts, will ultimately yield important insights for decision-making particularly at the regional scale.

\section{Summary of the regional Development Narratives}

In the following, we provide brief highlights of the regional Development Narratives (see also Fig. 1). The full storylines 
Fig. 2 Process of co-production of knowledge for determining the Development Narratives presented in the regional impact papers at the example of the LAC, MENA and CA papers of this special feature. Light blue boxes indicate important milestones of the project, green boxes indicate interactions within the World Bank, the violet box indicates interactions within the scientific partners, and the orange box indicates interactions with the World Bank regional experts and with external scientists/experts (in bold)

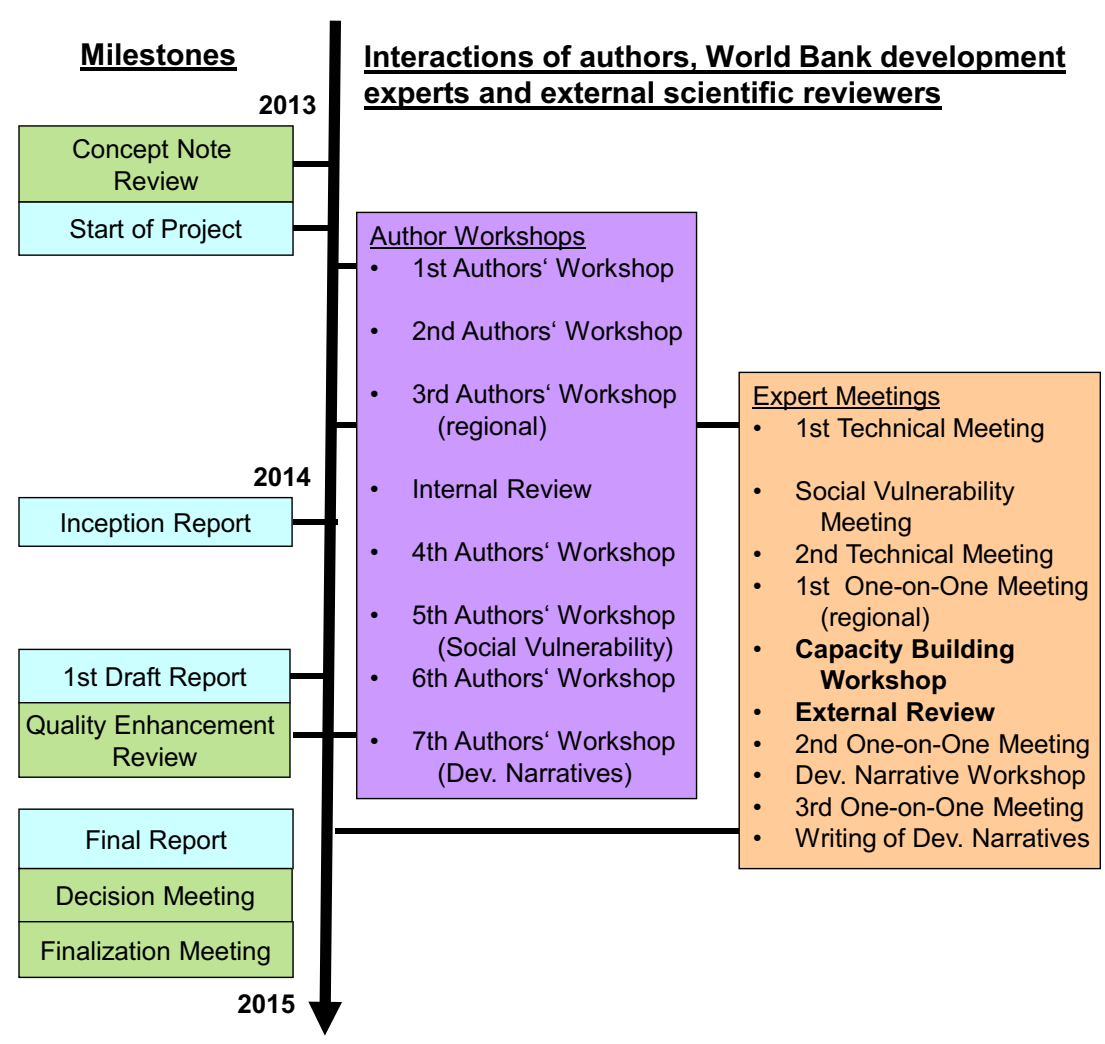

can be found in the respective regional impact papers. In Latin America and the Caribbean (Reyer et al. 2017b), climate change endangers small and large-scale agricultural production, freshwater supplies and ecosystem services. Stronger extreme events are projected to affect both rural and urban communities, particularly living on steep slopes and in coastal regions. In Middle East and Northern Africa (Waha et al. 2017), climate change threatens agricultural production, food security, water availability and public health and acts as a threat multiplier for the security situation in the region. Within Sub-Saharan Africa (Serdeczny et al. 2017), East Africa is strongly affected by flooding while West Africa might face agricultural production losses combined with declining oceanic productivity and densely populated coastal cities in the whole region face increasing risk from sea-level rise. In East Africa, climate change will affect public health and damage infrastructures while in West Africa food security and employment are at risk. In Central Asia (Reyer et al. 2017a), water resources might increase during the first half of the century leading to higher flood risk and decline thereafter, amplifying the competition for water between hydropower generation and irrigation to avoid declining agricultural production. In South Asia (Vinke et al. 2017), changes in tropical cyclones, precipitation patterns and river flows would affect the population through changes in floodings, droughts and agricultural yield losses. The ensuing food price shocks and health risks such as childhood stunting, transmission of waterborne diseases and disorders associated with excess salinity would particularly affect the poor.

\section{Conclusions}

The papers presented in this special feature relate regional climate impacts and their implications for human development to global warming levels $\left(1.5,2,3\right.$ and $\left.4{ }^{\circ} \mathrm{C}\right)$. Thus, they allow to assess the relevance of global climate policy for key development regions of the world. Moreover, they provide crucial input for the upcoming IPCC Special Report on $1.5^{\circ} \mathrm{C}$ warming and ensuing climate risk assessments (e.g. O’Neill et al. 2017) as well as adaptation planning (Kilroy 2015).

The papers show that all regions covered in the regional impact papers are facing climate impacts even if climate warming is limited to 1.5 or $2^{\circ} \mathrm{C}$ above pre-industrial levels. Warming of around $4{ }^{\circ} \mathrm{C}$ in many cases has disastrous consequences and natural and human systems and would seriously challenge promoting human development and ending poverty. These findings are compounded by a review of social vulnerability showing that the poor, elderly and children are often hit hardest by climate change.

The work presented in this special feature is the product of a 3-year inter- and transdisciplinary interaction between researchers and development practitioners of the World Bank. This interaction amalgamates hard scientific evidence with findings from a semi-structured stakeholder consultation with leading regional development experts leading to plausible Development Narratives of how climate change may impair development and poverty 
reduction efforts. The Development Narratives presented in each of the regional impact papers highlight the value of this co-production of knowledge to integrate climate change impacts across sectors and carve out their relevance for human development. This knowledge should help to gain a better understanding of the relationship between climate and development, bring up novel research questions and ultimately contribute to sustainable development under changing climatic conditions.

Acknowledgements The research presented in this special feature has been funded through the World Bank Project "Turn Down the Heat" and we are grateful to everybody involved in this activity for making it a success. Moreover, we would like to thank Wolfgang Cramer and Gabriele Götz making this Special Feature possible and for their valuable guidance throughout this process. CPOR acknowledges funding from the German Federal Ministry of Education and Research (BMBF, grant no. 01LS1201A1). We are grateful to the Inter-Sectoral Impact Model Intercomparison Project (ISIMIP) for providing the climate data.

\section{References}

Albrecht G, Sartore GM, Connor L, Higginbotham N, Freeman S, Kelly B, Stain H, Tonna A, Pollard G (2007) Solastalgia: the distress caused by environmental change. Australasian Psychiatry: Bulletin of Royal Australian and New Zealand College of Psychiatrists 15(Suppl 1):S95-S98. doi:10.1080/10398560701701288

Church JA, Clark PU, Cazenave A, Gregory JM, Jevrejeva S, Levermann A, Merrifield MA, Milne GA, Nerem RS, Nunn PD, Payne AJ, Pfeffer WT, Stammer D, Unnikrishnan AS (2013) "Sea level change." Climate change 2013: the physical science basis. Contribution of working group I to the fifth assessment report of the intergovernmental panel on climate. Cambridge University Press, Cambridge

Fawcett AA, Iyer GC, Clarke LE, Edmonds JA, Hultman NE, McJeon HC, Rogelj J, Schuler R, Alsalam J, Asrar GR, Creason J, Jeong M, McFarland J, Mundra A, Shi W (2015) Can Paris pledges avert severe climate change? Science 350(6265):1168-1169. doi:10. 1126/science.aad5761

Füssel HM (2007) Vulnerability: a generally applicable conceptual framework for climate change research. Glob Environ Chang 17(2):155-167. doi:10.1016/j.gloenvcha.2006.05.002

Hinkel J, Lincke D, Vafeidis AT, Perrette M, Nicholls RJ, Tol RSJ, Marzeion B, Fettweis X, Ionescu C, Levermann A (2014) Coastal flood damage and adaptation costs under 21 st century sea-level rise. Proc Natl Acad Sci 111.9(2014):3292-3297. doi:10.1073/pnas. 1222469111

IPCC (2013) Summary for policymakers. In: Stocker TF, Qin D, Plattner GK, Tignor M, Allen SK, Boschung J, Nauels A, Xia Y, Bex V, Midgley PM (eds) Climate change 2013: the physical science basis. Contribution of working group I to the fifth assessment report of the intergovernmental panel on climate change. Cambridge University Press, Cambridge. doi:10.1017/CBO9781107415324.004

IPCC (2014) Summary for policymakers. In: Field CB, Barros VR, Dokken DJ, Mach KJ, Mastrandrea MD, Bilir TE, Chatterjee M, Ebi KL, Estrada YO, Genova RC, Girma B, Kissel ES, Levy AN, MacCracken S, Mastrandrea PR, White LL (eds) Climate change 2014: impacts, adaptation, and vulnerability. Part A: global and sectoral aspects. Contribution of working group II to the fifth assessment report of the intergovernmental panel on climate change.
Cambridge University Press, Cambridge, pp 1-32. doi:10.1080/ 01944363.2014 .954464

Kilroy (2015) A review of the biophysical impacts of climate change in three hotspot regions in Africa and Asia. Reg Environ Chang 15: 771-782. doi:10.1007/s10113-014-0709-6

Leichenko R, Silva JA (2014) Climate change and poverty: vulnerability, impacts, and alleviation strategies. Wiley Interdiscip Rev Clim Chang 5(4):539-556. doi:10.1002/wcc.287

Morrissey J, Oliver-Smith A (2013) Perspectives on non-economic loss and damage: understanding values at risk from climate change. Loss and damage series. United Nations University Institute for Environment and Human Security, Bonn. http://loss-and-damage. net/4933. Accessed 16 June 2017

Newell B, Crumley CL, Hassan N, Lambin EF, Pahl-Wostl C, Underdal A, Wasson R (2005) A conceptual template for integrative humanenvironment research. Glob Environ Chang 15(4):299-307. doi:10. 1016/j.gloenvcha.2005.06.003

O’Neill BC, Oppenheimer M, Warren R, Hallegatte S, Kopp RE, Pörtner HO, Scholes R, Birkmann J, Foden W, Licker R, Mach KJ, Marbaix P, Mastrandrea MD, Price J, Takahashi K, van Ypersele JP, Yohe G (2017) IPCC reasons for concern regarding climate change risk. Nat Clim Chang 7:28-37. doi:10.1038/nclimate3179

Otto IM, Reckien D, Reyer CPO, Marcus R, Masson VL, Jones L, Norton A, Serdeczny O (2017) Social vulnerability to climate change: a review of concepts and evidence. Reg Environ Change 1-12. doi: 10.1007/s10113-017-1105-9

Piontek F, Müller C, Pugh TAM, Clark DB, Deryng D, Elliott J, Colón González Fde J, Flörke M, Folberth C, Franssen W, Frieler K, Friend AD, Gosling SN, Hemming D, Khabarov N, Kim H, Lomas MR, Masaki Y, Mengel M, Morse A, Neumann K, Nishina K, Ostberg S, Pavlick R, Ruane AC, Schewe J, Schmid E, Stacke T, Tang Q, Tessler ZD, Tompkins AM, Warszawski L, Wisser D, Schellnhuber HJ (2014) Multisectoral climate impact hotspots in a warming world. Proc Natl Acad Sci 111(9):3233-3238. doi:10. 1073/pnas.1222471110

Rahmstorf S (2007) A semi-empirical approach to projecting future sealevel rise. Science 315(5810):368-370. doi:10.1126/science. 1135456

Reyer CPO, Otto IM, Adams S, Albrecht T, Baarsch F, Cartsburg M, Coumou D, Eden A, Ludi E, Marcus R, Mengel M, Mosello B, Robinson A, Schleussner CF, Serdeczny O, Stagl J (2017a) Climate change impacts in Central Asia and their implications for development. Reg Environ Change 1-12. doi: 10.1007/s10113-0150893-Z .

Reyer CPO, Adams S, Albrecht T, Baarsch F, Boit A, Trujillo NC, Cartsburg M, Coumou D, Eden A, Fernandes E, Langerwisch F, Marcus R, Mengel M, Mira-Salama D, Perette M, Pereznieto P, Rammig A, Reinhardt J, Robinson A, Rocha M, Sakschewski B, Schaeffer M, Schleussner CF, Serdeczny O, Thonicke K (2017b) Climate change impacts in Latin America and the Caribbean and their implications for development. Reg Environ Change 1-21. doi: 10.1007/s10113-015-0854-6

Schaeffer M, Hare W, Rahmstorf S, Vermeer M (2012) Long-term sealevel rise implied by $1.5{ }^{\circ} \mathrm{C}$ and $2{ }^{\circ} \mathrm{C}$ warming levels. Nat Clim Chang 2(12):867-870. doi:10.1038/nclimate1584

Schellnhuber HJ, Hare W, Serdeczny O, Adams S, Coumou D, Frieler K, Martin M, Otto IM, Perrette M, Robinson A, Rocha M, Schaeffer M, Schewe J, Wang X, Warszawski L (2012) Turn down the heat: why a $4^{\circ} \mathrm{C}$ warmer world must be avoided. The World Bank, Washington DC. doi:978-1-4648-0053-5

Schellnhuber HJ, Hare B, Serdeczny O, Schaeffer M, Adams S, Baarsch F, Schwan S, Coumou D, Robinson A, Vieweg M, Piontek F, Donner R, Runge J, Rehfeld K, Rogelj J, Perette M, Menon A, Schleussner CF, Bondeau A, Svirejeva-Hopkins A, Schewe J, Frieler K, Warszawski L, Rocha M (2013) Turn down the heat: climate extremes, regional impacts, and the case for resilience-full 
report. The World Bank, Washington DC. doi:10.1596/978-1-46480055-9

Schellnhuber HJ, Reyer C, Hare B, Waha K, Otto IM, Serdeczny O, Schaeffer M, Schleußner CF, Reckien D, Marcus R, Kit O, Eden A, Adams S, Aich V, Albrecht T, Baarsch F, Boit A, Canales Trujillo A, Cartsburg M, Coumou D, Fader M, Hoff H, Jobbins G, Jones L, Krummenauer L, Langerwisch F, Le Masson V, Ludi V, Mengel M, Möhring J, Mosello B, Norton A, Perette M, Pereznieto P, Rammig A, Reinhardt J, Robinson A, Rocha M, Sakschewski B, Schaphoff S, Schewe J, Stagl J, Thonicke K (2014) Turn down the heat: confronting the new climate normal. Washington D.C, The World Bank. doi:10.1596/978-1-4648-0437-3

Schewe J, Heinke J, Gerten D, Haddeland I, Arnell NW, Clark DB, Dankers R, Eisner S, Fekete B, Colón-González FJ, Gosling SN, Kim H, Liu X, Masaki Y, Portmann FT, Satoh Y, Stacke T, Tang Q, Wada Y, Wisser D, Albrecht T, Frieler K, Piontek F, Warszawski L, Kabat P (2014) Multi-model assessment of water scarcity under climate change. Proc Natl Acad Sci USA 111:3245-3250 doi:10. 1073/pnas. 1222460110

Schleußner CF, Mengel M (2017) Warming attribution calculator. Available at: http://wlcalc.climateanalytics.org/choices. Accessed 9-5-2017

Serdeczny O, Adams S, Baarsch F, Coumou D, Robinson A, Hare W, Schaeffer M, Perrette M, Reinhardt J (2017) Climate change impacts in Sub-Saharan Africa: from physical changes to their social repercussions. Reg Environ Change 1-16. doi: 10.1007/ s10113-015-0910-2
Tschakert P (2015) $1.5^{\circ} \mathrm{C}$ or $2{ }^{\circ} \mathrm{C}$ : a conduit's view from the sciencepolicy interface at COP20 in Lima, Peru. Clim Change Resp 2.1:3. doi:10.1186/s40665-015-0010-z

Tschakert P, van Oort B, St. Clair AL, LaMadrid A (2013) Inequality and transformation analyses: a complementary lens for addressing vulnerability to climate change. Climate and Development 5(4):340 350. doi:10.1080/17565529.2013.828583

Vinke K, Martin MA, Adams S, Baarsch F, Bondeau A, Coumou D, Donner RV, Menon A, Perrette M, Rehfeld K, Robinson A, Rocha M, Schaeffer M, Schwan S, Serdeczny O, Svirejeva-Hopkins A (2017) Climatic risks and impacts in South Asia: extremes of water scarcity and excess. Reg Environ Change 1-15. doi: 10.1007/ s10113-015-0924-9

Waha K, Krummenauer L, Adams S, Aich V, Baarsch F, Coumou D, Fader M, Hoff H, Jobbins G, Marcus R, Mengel M, Otto IM, Perrette M, Rocha M, Robinson A, Schleussner CF (2017) Climate change impacts in the Middle East and Northern Africa (MENA) region and their implications for vulnerable population groups. Reg Environ Change. doi:10.1007/s10113-017-1144-2

Warszawski L, Frieler K, Huber V, Piontek F, Serdeczny O, Schewe J (2014) The inter-sectoral impact model intercomparison project (ISI-MIP): project framework. Proc Natl Acad Sci USA 111: 3228-3232 doi: 10.1073/pnas.1312330110

WMO (2017) WMO statement on the state of the global climate in 2016. World Meteorological Organisation, Geneva 